\title{
The Pursuit of Primordial Interest as an Explanatory Factor for the Prevalence of Governance Crisis in Nigeria's Fourth Republic
}

\author{
B. T. Badejo ${ }^{1}$, S. C. Agunyai ${ }^{2} \&$ S. O. Buraimo ${ }^{2}$ \\ ${ }^{1}$ Department of Local Government Studies, Obafemi Awolowo University, Ile-Ife, Nigeria \\ ${ }^{2}$ Department of Political Science, Obafemi Awolowo University, Ile-Ife, Nigeria \\ Correspondence: S. C. Agunyai, Department of Political Science, Obafemi Awolowo University, Ile-Ife, Nigeria. \\ E-mail: Samora20032008@yahoo.com
}

$\begin{aligned} & \text { Received: November 11, } 2014 \quad \text { Accepted: November 16, } 2014 \quad \text { Online Published: June 26, } 2015 \\ & \text { doi:10.5539/jpl.v8n3p1 }\end{aligned} \quad$ URL: http://dx.doi.org/10.5539/jpl.v8n3p1

\begin{abstract}
The prevalence of governance crisis in Nigeria is obvious. Inadequate structural facilities continue to impede quality of life while public office holders live in opulence. With abundant resources serving the interests of the individual in positions of power, the Nigerian state continuously slides backward in sustainable development. This paper investigated effect of illicit satisfaction of politician's cronies' selfish interests over national interest on governance crisis. The paper contended that politicians cronies in a bid to satisfy their primordial interests unduly revel, worship and perpetually make demands on leaders as soon as they ascends power. This in turn propel political officeholders to abandon provision of public good in a bid to satisfy the quests of their cronies. Since they rely on public treasury to satisfy these needs, political leaders therefore resort to looting to access sufficient fund. The paper argued that proclivity towards satisfying the quests of politicians' cronies at the expense of public goods aggravates governance crisis in Nigeria. Thus, corrupt public office holders continue to enjoy the support and receive accolades from the people who benefitted thereof. The paper further argued that, in spite of efforts of anti-corruption agencies and civil society organizations in the fight against impunity and bad governance in Nigeria, the effective and rapid promotion of good governance demands a multi-faceted approach in its practice as it affects democracy in Nigeria. To this end, the paper suggested additional ways of addressing the problem of primordial interests and governance crises in Nigeria.
\end{abstract}

Keywords: cronies, governance crisis, national interest, primordial interest

\section{Introduction}

Political inquest and academic discourse in the study of governance, particularly in respect of governance crisis in Nigeria is prompted by unfortunate cases of impunity, corruption, display of ethnic bias, non-adherence to democratic tenets by public office holders and unwarranted celebration and accolades of politicians by their cronies. Governance crisis has thus triggered studies designed to address this menace, considering the benefits of good governance to a nation. Also, in Nigeria, policies that can enhance good governance, promote national interest and consolidates the nation's democracy have been articulated and enforced in a bid to control perceived cases of excessive crave for primordial interests over civic interests by the cronies of public office holders, but it seems these policies are only good as their names suggests on the surface and not effective in resolving governance crisis.

In Nigeria, since return to democracy in 1999, political leaders have always been accused and blamed for bad governance and low sustainable development. Not unexpectedly, public office holder including politicians have been subjected to various accusations for causing bad or governance crisis in Nigeria. The foregoing notwithstanding, not much intellectual resources have been deployed to investigating the roles, cronies of politicians (relations, friends, party loyalist, associates and Godfathers) plays in governance crisis in Nigeria.

These cronies constitutes friends, associates, loyalists and Godfathers of politicians or public office holders as well as ethnic group to which public office holders belongs to, who most times were the first persons to congratulate leaders or politicians who have just ascend positions of governance. These group of people (cronies), according to observations (in Channels Television News) of cases of political violence at All Progressive Party (APC) gubernatorial campaign in Okrika, Rivers State and that of People Democratic Party 
(PDP) Presidential campaign in Bauchi and Kastina in the just concluded 2015 general elections tend to be culpable of the offence of crave for inordinate satisfaction of their selfish interests, which more often than not, propels them in engaging in criminal activities on behalf of their leaders or politicians at party's rallies and campaigns. These politicians, especially those in positions of governance in turn resorts to looting of public funds to satisfy their cronies' quest. The consequence of this, is governance crisis because it adversely affects delivery of public goods to the people, accountability, rule of law and transparency in governance.

\subsection{Statement of the Problem}

The pursuit of primordial interest over national interest leading to governance crisis, have remained a recurring phenomenon in Nigerian politics. This phenomenon has, at various times attracted scholarly attention. Though researches have been conducted in this direction, but there is a dearth of empirical studies on the subject, especially in relation to the new dimensions of governance crisis resulting from the need to satisfy the quest for selfish interests of cronies of politicians' in an attempt to get more votes in the general election, hence the study.

\subsection{Research Questions}

1.2.1 How have actions of cronies of politicians towards pursuit of selfish interests led to governance crisis in Nigeria?

1.2.2 What are the implications of pursuit of primordial interests on governance in Nigeria?

\subsection{Objective of the Study}

The basic issue to which this paper addresses itself, is to, in an exploratory manner; investigate the extent to which actions of cronies of politicians and there crave for primordial interests over national interests have aided governance crisis in Nigeria. The paper is interested in investigating how the actions of the cronies of politicians has unduly influence political office holders toward bad governance or governance crisis in Nigeria.

\subsection{Research Assumptions}

1.4.1 Inordinate crave for primordial interest over national interest by cronies of politicians' promote tendency of crisis driven governance in Nigeria.

1.4.2 The pursuit of selfish motives and implementation of policies in bid to satisfy primordial motives of politicians' cronies undermine efficient delivery of common good and rule of law in Nigeria.

This paper in its attempt to address the research questions and assumptions is divided into five sections. Section one contains the introduction; section two, consists of conceptual and theoretical frameworks. The third section contains of manifestations of primordial interest in Nigeria and actions/roles of cronies of public office holders that engenders governance crisis. The fourth section contains the research method, discussion of findings and the need for the people of Nigeria to promote national interests over primordial sentiments is also highlighted. Section five contains the conclusion.

\subsection{Study's Methodology}

Being essentially a reflexive exploratory study, relevant qualitative data collection techniques (in-depth interviews [IDIs]) were utilized in generating primary data for the study from key respondents who were mainly public office holders/politicians, public policy analyst/academics. The criterion for selection of these group of people was based on their adequate knowledge or expertise of what can cause governance crisis and implication of pursuit of primordial values over national values for good governance. In each region, politicians, public policy analyst and academics were selected from the identified group of key respondents. This was done in order to provide the study with useful first-hand information on the nature of pursuit of primordial interests by cronies of politicians and mode of governance crisis in each region. Descriptive and content analysis were engaged in data analysis.

\section{Conceptual Framework}

\subsection{The Concept of Governance}

The word governance has received considerable attention in the literature. It refers to the process of formulating policies and implementing them based on several considerations that are premised on respect for the rule of law and order, provision of necessities that enhance human dignity, observance of fundamental rights, popular participation in the democratic process, equity, transparency, accountability and unhindered access to information amongst others (Nnonyelu, 2013:102). Africa Leadership Forum (2000) defines it as 'the ability of a government to effectively manage resources of the state in such a manner that it is capable of providing for the basic needs of the people and the people are allowed to develop their full potentials under a democratic political 
framework based on the rule of law'. In similar vein, Ogundiya (2010: 202), posited that governance is simply the process that is employed to achieve the noble end of the state which is, the promotion of the common good. Governance, whether good or bad depends on how this 'common good' is distributed or implemented. To Inokobar and Kumokor, (2012: 139-148), governance is viewed as the process by which a political system achieves such values as accountability, participation, openness (or transparency) and respect for the rule of law and due bureaucratic process.

A critical look at the definitions of governance by scholars above show that the concept, is a process of ensuring equitable distribution of the country's resources on the basis of rule of law which in turn enhances accountability and promote popular participation in politics. Governance in the real sense connotes service to the people in bid to satisfy national interests over primordial values. Governance could be good or crisis driven. It becomes good, when those at the helm of affairs follows strictly the law of the land in dispensing the state's resources, allowing themselves be held accountable and shunning selfish interest for national interests as well as exhibiting an exemplary leadership style. Again, governance is good, when citizens' interests is the priority of leaders and not theirs or their cronies. It becomes crisis driven, when distribution of common good to the people is override by the urge and crave for primordial values ahead of the national values. In this wise, governance crisis refers to the apparent and obvious inability of public institutions to deliver on infrastructure - water, roads, power, healthcare, food, employment and security. Crisis is inevitable in a situation where leaders lacks the political will to deliver common good to the generality of the people rather than to the benefit of themselves or their cronies. It is important to note that, governance is not free of crisis in Nigeria because of the tendency of leader's quest to satisfy their selfish interests and that of their cronies over civic interests. This view was corroborated by Akinboye \& Anifowose (cited in Oni, 2013), when they contends that governance is recognized as the most critical challenge for political and socio-economic development in Africa, and particularly in Nigeria. More than fifty years after Nigeria gained political independence in 1960, the country is still faced with the problem of adopting the right model of governance (Oni, 2013).

\subsection{The Concept of Primordial Interest}

These are qualities, principles and behaviours which selfish people held in high esteem for intensive desire of themselves or their ethnic group. It is the process whereby Nigerian society is configured for the interest of few individual elites, ethnic group, and friends and not for the populace. Philosophically, the entity wallow in a shallow, deep memory that no leader is ready to sacrifice his life to better the country instead he loots the country's resources for self-enrichment Odeh (cited in Nnamani and Illoh, 2014: 27), coupled with parochial instinct among ethnic cleavages in Nigeria. This is essentially a system of shared identity and social solidarity expressing itself through a circuit which concentrates and redistributes income; and exclusion is a result of the absence of social bond between the insiders and the outsiders (Dommen, 1997: 493). In the same vein, it is a situation whereby procedures governing the operation of state offices are used as fig-leaves behind which state resources are appropriated; and under the confiscatory system, government officials simply seize public assets without even attempting to camouflage their behaviour behind rules and procedures (Joseph, 1999: 49-50).

\section{Theoretical Framework}

Theoretically, the paper adopts the elite theory in explaining primordial interests as explaining factor of governance crisis in Nigeria's fourth republic. This theory holds the view that political power resides in a few in the society while the majority are led. Elites, according to the proponents of the theory, Gaetano (1939); Michels (1942); have features as wealth, intelligence, special skills, moral character, and hosts of others. The theory holds the view that the society is made of two classes the higher stratum, the elite that is further divided into the ruling class or governing and non-governing elite, and a lower stratum or non-elite. The governing class formulates and implements policies that are binding on the entire people in a state, and the theory observed that the parochial/primordial interests of the elites tends to reflect more than the national interests on policies formulated and implemented in the state. The connection of this theory to explaining primordial interests as factor exacerbating governance crisis in Nigeria essentially lies within the context of our leaders, their cronies and other public office holders who have allowed there selfish interests to override the country's national interests. In Nigeria, public policy meant to promote accountability, popular participation in politics, respect for fundamental human rights and distribution of common goods are left un-implemented, even when it is implemented, it is usually done to promote the interests of their cohorts, it has been noted also that policies that will promote impunity, corruption and ethnic divide are enforced by those in governance all in the name to satisfy their idiosyncrasies and selfish motives. For instance, one of the major problem with government policy in Nigeria is misplaced priorities. It means policy meant for the beneficiary of the people is hijacked by certain group or persons who are closer to the politicians or government, leaving the poor masses to wallow in abject poverty. 
There are cases where policy are implemented to swell the pockets of party loyalists, friends and other cronies. The case that readily comes to mind is the policy of better life for rural women that was hijacked by the wives of politicians. This in the long run promote bad governance as majority of the people are skewed away from national development.

\section{Manifestations of Primordial Interests in Nigeria}

Manifestations in this regard, means signs, indices or ways and manners through which primordial interests is displayed in Nigerian society. It is simply indicators that describes how selfish/primordial interests is exhibited. In Nigeria, primordial interest is manifested in ethnic bias, self-enrichment, corruption, abuse of public office, impunity among others. Ethnically, Nnoli (1978), reiterated that the basis of the ethnic prejudice found in a plural society of Nigeria is anchored on national disunity that breed primordial sentiment which relegates universalism at the background and hampers national development at different point in time. In a similar vein, Osaghe (2001), contends that the criterion for locating public industries in Nigeria is on ethnic line than the suitability on the area of development, and this excludes sharing of scarce resources. In a more revealing approach, Osaghae (1994:44), notes that ethnicity is problematic phenomenon whose character is conflictual rather than consensual. Having enumerated the features of ethnicity on which scholars agreed. The author stressed that ethnicity is a conscious behaviour based on ethnic identity or loyalty in a competitive situation involving more than one such identity, which is aimed at furthering interests of the individual and/or group.

It can be inferred from Osaghae's view that primordial interest is manifested when people tend to project and pursue strictly their interest at the expense of national value in a competitive situation. This could take the form of a situation where public office holders pursue policies that can only be beneficial to him and his group leaving the entire populace to wallow in muddles. In Nigeria, there are cases of governors and local government chairmen who had used their position to attract incentives and social services meant for the state and entire local government area to their village and constituency. Maier (2000: 23) aptly corroborated this view where he contends that:

... Rare is the head of state who acts on behalf of the entire nation. The people are not so much governed as ruled. It is as if they live in a criminally mismanaged corporation where the bosses are armed and have barricaded themselves inside the company safe. Nigeria's leaders, like the colonialists before them, have sucked out billions of dollars and stashed them in Western banks.

Also, primordial interest has been displayed through self- aggrandisement in Nigeria. One major problem which has plagued Nigeria and its people since return to democracy in 1999 has been poor governance propelled by the greed and myopia of some selfish people (politicians' cronies) who in an attempt to assuage their primordial interest for lucrative contract, appointment, favour and gifts unduly influence, pressurise or pushes leaders to steal or loot public funds and this in return leaves leaders with little or nothing to expend on service delivery, it makes them unaccountable, corrupt and largely unlawful, consequently leading to a situation of governance crisis. For Nigerian leaders and their cronies, governance has always been about plundering of the country's resources and the accumulation of wealth at the country's expense. In a recent interview on the platform of Sunrise Daily, Channels television, Gbanite (2014), contends that the cronies of politicians are more prone to satisfying their selfish interests which in the long run unduly compels public office holders' to loot public treasury to satisfy their cronies quest.

Primordial interest is also indicated through secular celebration or undue apple-polishing of leaders in position of governance. It is no more new story that some people known as the cronies of public office holders, who because of poverty and sense of customary slogan that "it is our own time or turn to rule, give us our own share of national cake" conspires with leaders in governance to loot public funds and satisfy their individual gains over national value. It is also displayed when an old school friends' visits newly elected leaders or appointed officers to greet them and repeatedly make undue demands that promote his own selfish interest. There are even cases where people have sang praises of corrupt leaders instead of rebuking them. This view was however strongly alluded by A. Otuaigbe (IDI, Male, Politician, Kwara State, and November, $17^{\text {th }}$, 2014) who reported that some selfish people in Bayelsa State tend to worship and celebrate their former governor, Alamiaseiye Depreiye who disguised as a woman and escaped jail term in London for an offence of money laundering. Also, the case of Bode George, former chairman of aviation board who after serving jail term for an offence of corruption and embezzlement of aviation funds was largely welcomed by the people who sang praises of him from prison (see national dailies of the time). The foregoing has reasonably shown that primordial interests also manifest in the way people makes illicit demands on those in governance. In Nigeria, the problem of governance crisis is not caused by the leaders alone but by people who unduly celebrate them because of incentives and personal gains 
they hope to enjoy.

Besides, primordial interest is also manifested in corrupt attitude displayed by some people. It becomes a corrupt action when people who are supposed to be rebuking and exposing leaders involved in corruption are the one protecting and welcoming them with warm hands. Corruption in the views of (Nye, 1967; Dobel, 1978; Amuwo, 2005; Obayelu, 2007; Fjeldstad and Isaksen, 2008; Ogundiya, 2009), is the exploitation of public position, resources, and power for private gain. For instance, in Nigeria's fourth republic there are numerous cases of primordial sentiments manifested through corruption such as award of contracts to friends at the expense of more qualified contractors. A good example supporting this assertion was the case of Senator Chimaroke Nnamani who had faced about 124 count charges of fraud, conspiracy, concealment and money laundering totalling about 5.4 billion naira (Vanguard, Saturday February 16, 2008). Also, Madam Patricia Etteh, the first female Speaker of the House of Representatives, resigned following her indictment over the misappropriation of public funds in multiple contracts of N628m (US\$5 million) for the renovation of her official residence and the purchase of 12 official cars. Suffice to say that many public office holders have abused their office to protect their personal interests at the expense of national values. Corruption has also had debilitating impacts on the rule of law, human rights and other supportive ingredients of democracy. The implication for good governance is seemingly destructive.

Corruption is the bane of governance crisis in Nigeria. For instance, when resources meant for the development and improvement of the state or local government area is illegally carted away by the leaders and their cohorts. Or how could there be good governance when leaders and their associates are busy dispensing the state treasury for their private gains? How can we have good governance when the activities of those in governance are against popular participation in politics or how could we escape from the problem of governance crisis when the leaders and their cronies in our communities are ethnically bias and largely not accountable to those who elected them? All these questions, no doubt are begging for answers in the face of governance crisis in Nigeria.

\subsection{Governance Crisis in Nigeria: The Actions/Roles of Cronies of Public Office Holders}

Events in Nigeria since 1999 have shown that the tidal waves of reversal have been contending with governance in Nigeria. Subsequently, governance crisis has been taken as a normal thing and customary in our country and the future seems to be very bleak because of rampant systemic bureaucratic and political corruption. Corruption has reached a high climax such that an average Nigerian now possibly associates governance with corruption. The consequences of political corruption are patently manifest: cyclical crisis of legitimacy, fragile party structure, institutional decay, chronic economic problem and underdevelopment and, above all, general governance volatility. In all these, cohorts of politicians or public office holders who are at the same time members of the society play no small role in engendering crisis in governance. It is important to elucidate, as clearly stated earlier in this paper that most researches on crisis of governance in Nigeria points accusing fingers to leaders, there have been dearth of academic focus on the impact the people or cronies' of politicians (community heads, friends, party members, ethnic group and family relations) plays in contributing to governance crisis.

Profound observations in a recently conducted interview have shown that in Nigeria, the community or ethnic groups from which public office holders' comes from tends to accord undue self-glorification or praise to their representatives to the extent that some of them tend to close their eyes to corrupt attitude and impunity of their representatives in government. Corroborating this view was the comments of some group or people in the South-South region where they openly commented that President Goodluck Jonathan must re-contest as the president of Nigeria for the second term or must not return to the region (see national dailies of the time). This comment, in itself is wrong, though there is nothing wrong in President Jonathan's bid to contest in the general election but the way and manner at which these group of people in South- South Region made the comment, was bad, threatening and could cause agitations from other ethnic groups.

The actions of political Godfathers who are partners or associates of politicians or public office holders across the six geo-political zones in satisfying their selfish interests had at one time or the other resorted into governance crisis in states like Oyo, Kwara, Borno and Anambra. Godfathers are wealthy and powerful citizens who may be strong business persons or party member who sponsors politicians in an election with the hope to make profit or demands on politicians they have illicitly enthroned in government. This view was aptly supported by Joseph (1981), who views godfatherism from "prebendal" perspective and contends that:

The holder gets to office based on the agreement that he or she will use such office to satisfy the demands of specific sub-sets of the general population. So, such a candidate remains popular or in office as long as he or she sticks to the agreement. Although, it is a relationship based on interdependency, it is actually a relationship 
between the weak and the strong.

In Nigeria, godfatherism remains one of the ills in the political process since 1999. This is because it has configured public office like an eatery which only the godfather alone gives the ticket to whoever he likes and once any beneficiary disobeys him, he gets him or her out of the eatery (Adebanwi 2010). From the foregoing, it is observed that actions of godfathers who are largely partners or associates of political leaders or elites can cause crisis in governance. This is because these godfathers have the means (money, power and connection) to enthrone and dethrone whoever they want to be in government. Crisis becomes prevalent or looms when the sponsored politicians or public office holders after gaining control of government, no longer satisfy the interests of their godfathers. This has been the major obstacles to good governance in some states in Nigeria. For instance, those in governance instead of pursuing national interests of providing public goods to the people, fostering accountability, respect for rule of law, justice in distribution of social amenities etc., were pre-occupied with satisfying the individualistic gains of their cronies. For instance, there have been cases of severe crisis in governance in Oyo State between Gov. Ladoja vs Late Adedibu, Late Saraki vs. Lawal in Kwara State, Offor vs. Mbadinunju (1999-2003), Uba vs. Ngige (2003-2006), in Anambra State, Kachalla vs. Alimodu Sherif in Borno State (2002-2003). In all these cases, the godfathers ensures the ousting (impeachment) of defying godsons who had acted contrary to the bond. This has had severe implications for participation in politics, accountability, service delivery, respect for rule of law and good governance not only in the affected states but Nigeria as a whole, because this action of cronies of politicians tends to have made godfatherism phenomenal and parasitic in Nigeria's fourth republic.

Furthermore, wealthy citizens and industrialist who are not political godfathers but have close affinity with those in government or public office holders have also been found guilty of the offence of contributing to bad governance or governance crisis in Nigeria. This is rather manifested in offering of bribe to public office holders to satisfy certain selfish interests of a wealthy business man. A good example of this, can be seen in the case of Otedola and Faruk Lawan over oil subsidy probe, where Faruk, an Honorable at the House of Representatives was accused of collecting bribe from Otedola an oil magnate, who offered Faruk bribe, in order to doctor or manipulate the report of the oil subsidy probe committee in favour of Zenon Oil and Gas owned by Otedola (Premium Times, Wednesday June 19, 2013 p.7). Crisis is inevitable in governance, when the country's resources (crude oil) meant to serve the good of the entire nation is carted away by some group of wealthy business persons who have close relationship with those in government.

Apart from the case of oil subsidy probe, the pension scam, the Security and Exchange Commission (SEC) probe and the bullet proof car case involving former minister of aviation all points to the fact that corrupt practices of some key members of the society have hugely contributed to crisis in governance in the country. In Nigeria, the rot in governance is exhibited by deliberate unruly corrupt action of some key members of the arms of government. For instance in Nigeria, members of legislature that supposed to exert some measures of checks and balances on the executive arm in terms of probing the executive members in case of corrupt practice are also found guilty of the same offence they are probing. This view can however be validated by the case of Security Exchange Commission (SEC) probe involving its Director General, Mrs. Arunma Oteh and the Chairman of the House Committee of the Capital Market and Honorable Herman Hembe where the latter, a member of the legislative arm was accused of demanding 44 million from the DG of SEC, a member of the executive arm (Abbah, Abdulhamid, Idris, Hassan, Ekundayo, \& Ogunwale, 2012).

Again, the activities of party loyalists of ruling government or party at all levels of government have been reinforcing the tendency of governance crisis in Nigeria. Cronies of ruling government or party have been observed to be using illicit means to ensure their candidates' returns as Governor elected at the state level and when the result of the election is not in their favour, they resort to violence and unconstructive criticism and unhealthy rivalry. This view was aptly supported by Idowu (2010:52), who contends that an assessment of election history in Nigeria would reveal that the quest for credible elections in the country had been marred by a number of security challenges. These include political assassination, political thuggery, ballot snatching, intimidation, arson, etc. In a similar vein, Rapoport and Weinberg (cited in Joshua, 2013:324-339) stated that the situation immediately after elections is often very sensitive as the acceptance or otherwise of the outcome of elections by cronies of politicians can produce outbreaks of violence. The paper contends that, this was evidenced in the announcement of presidential election in 2011, which saw Goodluck Jonathan as the country's President, there were cases of riots, violence civil unrest in some parts of the Northern Nigeria. The incessant cases of electoral violence caused by cronies of politicians and public office holders made Gidado (2010), to contend that the nature, extent of youth involvement in electoral violence, and magnitude of violence associated with elections and rigging in Nigeria are posing threats to the national quest for a stable democratic transition, as 
well as to the attainment of consolidated democracy'.

A critical look at the foregoing, reveals that cronies (friends, loyalists, godfathers, business magnates, ethnic groups etc) of public office holders or ruling government have at one time or the other played major illicit roles in exacerbating the problems of governance crisis, which they have openly displayed by engaging in corrupt practices, electoral violence, offering of bribe, sponsoring of candidates/politicians in an election for profiteering, undue worship/celebration of leaders in public offices in order to get lucrative contract even when they are not qualified for it and unconstructive criticism and opposition of other governments or party's members.

It is imperative to note that Nigerian government in an attempt to redeem its image of fighting corruption and impunity has always deployed the means of probe which yields little or no success. However, below are some of the incessant probes that do not yield public reports under this current administration and rob Nigerian citizens of their commonwealth and scarce resources. In spite of this, many well documented reports on corruption suggest laxity and lack of interest to deal with corruption in Nigeria. These reports, as noted by the Centre for Democracy and Development include the following:

1. The KPMG report in which the Nigeria National Petroleum Corporation (NNPC) was indicted for corrupt practices and short changing Nigerians.

2. The Nigeria Extractive Industries Transparency Initiative (NEITI) audit report exposing 10 years of corruption in the upstream and downstream sectors of the oil and gas industry.

3. The probe of the Pension Fund Management by the Senate Joint Committee on Public Service and Establishment, State and Local Government Administration.

4. The case of corruption and money laundering trial against ex-Delta State Governor James Ibori in the UK for which he has reportedly pleaded guilty despite the acquittal granted him by a Nigerian court.

5. The SEC probe and the alarming revelations of corruption in the capital market.

6. The probe of the oil subsidy regime by an Ad hoc committee of the House of Representatives.

7. The bribe scandal against Hon. Faruk Lawan, chairman of the House Adhoc Committee on Petroleum Subsidy.

8. The impunity by some state governors in their refusal to allow for local governments council elections.

9. The non-prosecution of those indicted in the Haliburton LNG bribery scandal; the same where the Americans involved had been prosecuted and charged in their country.

10. The integrity of the legislature has come under serious suspicion with the too frequent accusation of the probe committee members of bribery.

11. The revelation by Shell Petroleum Development Company that Nigeria has since 2009 lost $\$ 1.5$ billion yearly to crude oil theft.

All these among others constitutes a major challenge to Nigeria's presidential system and breeds governance crisis in Nigeria (Centre for Democracy and Development, 2013).

\section{Content Analysis of Qualitative Data (IDIs)}

This study utilizes data obtained through interview of 6 key informants/respondents who are either public office holders'/politicians or public policy analyst/academicians for a descriptive explanation of findings. Specifically, for the qualitative data, extracts of interviews conducted were presented and analysed using the research assumptions of this study as a guide and they are restated thus:

1. Inordinate crave for primordial interest over national interest by cronies of politicians' promote tendency of crisis driven governance in Nigeria

2. The pursuit of selfish motives and implementation of policies in bid to satisfy primordial motives of politicians' cronies undermine efficient delivery of common good and rule of law in Nigeria

In analysing these assumptions, relevant questions in the question guide were used. This was done to elicit rich and comprehensive data for the research.

Assumption 1: "Inordinate crave for primordial interest over national interest by cronies of politicians' promote tendency of crisis driven governance in Nigeria". To analyse this assumption, the following question was inquired from the identified key respondents

Question: How have actions of cronies of politicians towards pursuit of selfish interests led to governance 
crisis in Nigeria? The aim of this question was to find out how pursuit of selfish interest over national values by cohorts of politicians has led to governance crisis in the country. For most of the respondents, the urge for self-aggrandisement has been more culpable for crisis prone governance in Nigeria. Almost all of them, if not all, responded in the affirmative that the need to satisfy friends, political godfathers' wishes, loyalist, one's ethnic group have been the cause of continual crisis in governance in Nigeria. On this issue, the response of Mr. Adedayo Ajayi, a public policy analyst in South-West was particularly revealing. For him ${ }^{1}$

Action of godfathers' in terms of sponsoring political godsons in elective positions, party loyalists unending demands on public office holders, biasness of ethnic group in singing praise of corrupt leaders who hails from their ethnic group and award of contract to friends, families and godfathers' of those in positions of power, prevents and limit the money that will be spend on delivery of common good to the populace. It will make leaders steal to satisfy their godfathers, friends and families interests over national values and this has been the cause of bad governance at all levels of government.

In support of this position, Akujioba, a politician in South-Eastern Nigeria, in his attempt to reveal the link between primordial interest and governance crisis in Nigeria contended that ${ }^{2}$ :

The wave of defection in the two leading parties in the country was borne out of chase for selfish motives than national motive by the defectors. Most crisis we see at the National Assembly, particularly the one at the lower legislative house was caused by the selfish interest of lawmakers who defected because of the gains or benefits they hope to enjoy in coming election. The executive arm is not different either in terms of granting selfish interest of cronies or formulating and implementing policies that promote selfish interests of their ethnic groups, godfathers' cronies and party loyalists. For instance, why do you think some of the executive Governors in this region abandoned conducting local government election and replacing the councils with appointed officers who are their cronies and party loyalists? This has definitely be responsible for unabated tendency of governance crisis in the country.

For A. Haruna (IDI, Male, Lecturer, Ahamadu Bello University, 50 years November, $19^{\text {th }}, 2014$ ), the people who gathered to eat or seek for one help or the other from politicians may not have the will to publicly criticise these politicians when they are caught looting state's treasury because they are both partner in the crime. For him ${ }^{3}$

High poverty and low education level in Northern Nigeria, has made people to continually make demands on public office holders for help, money, job and contract award. This in turn make these people to close their eyes to corrupt attitude of their friends in position of powers. You know that this action will cause bad governance because there will be no accountability, delivery of efficient service and corruption.

It is important to note that high illiteracy rate and poverty are factors influencing the actions of the cronies of politicians in the North towards the pursuit of selfish interest. And this has had adverse effect on good governance as the people can no longer hold government accountable because they have soiled their hands in the dirty waters of the politicians. This view was further echoed by Danladi Murmur former councillor in Giade Local Government, Bauchi. To him ${ }^{4}$

People in our villages and towns converge to eat and dinned with the politicians in their houses on the same mat, plate and room. How do you expect such people to question their helper for accountability? They even fight people who criticised their leaders openly and commit criminal offences (such as beating of political opponents, stealing of election materials during election, engaging in riots and other violence on behalf of their leaders all in the name to be amply rewarded by the politicians.

The revelations from the views of key respondents shows that governance crisis is inevitable where there is 
inordinate desire for selfish interests by the cronies of politicians. And this governance crisis will eventually manifests in the form of poor accountability, no respect for law, inefficient delivery of common good or service. The words of Mrs. Akahnene Eunice, Women leader in Labour Party, Warri, Delta State sums it up

In reality, the actions/interest of cronies and friends of politicians to a larger extent determine the policies and programmes of the government. For instance in recent election campaigns across the South-South region, most public office holders and politicians tends to have satisfy and meet some of the demands of their cronies all in the name to get more votes. What do you think will happen if such politician wins the election? Wouldn't he loot public treasury to get back his money? Or will he not continue to appease his cronies by granting their request at the expense of national interest? All these questions are clear evidence that there is bound to be crisis in governance if our elected public office holders continue to grant the wish of their cronies over core national issues.

Assumption 2: "The pursuit of selfish motives and implementation of policies in bid to satisfy primordial motives of politicians' cronies undermine efficient delivery of common good and rule of law in Nigeria". To analyse this assumption, the following question was inquired from the identified key respondents.

Question: How can the pursuit of primordial interests or implementation of policies that promotes selfish motives of politicians' cronies affects effective delivery of common good and rule of law? This question intends to identify if promotion of selfish motives of cronies of politicians through policy formulation affects governance in Nigeria. To some of the key respondents, the cronies of politicians made illicit demands on the politicians than the masses who have elected them into power. The godfathers' of politicians' for instance, even go the extent of pushing for slots for commissioners, special advisers and government appointments in the state. The texts of the following IDIs seem to be in appropriate consonance:

.....The fight between Chris Ngige and Chris Uba in this state was because the Godfather, Chris Uba was making huge demands on Chris Ngige, the then Governor of Anambra State over appointment of commissioners and other vital officers in the state (IDI, Male, Public Policy Analyst, 45 years, Anambra State, November, 19th, 2014).

...Look at the PDP and APC campaigns, the way politicians' thugs and cronies are shooting guns and causing political violence at elections campaign. Lives and properties have been destroyed, even police force has loose some of its officers. These cronies are doing this in pursuit of their selfish motives. In this country, politicians tend to protect the right of their cronies who illicitly fought for their enthronement at the expense of the interests of the masses. This in recent times has been responsible for inefficient service delivery (IDI, Female, Women Leader, 38 years, Kogi State, November, 19th, 2014).

Generally, the problem of governance crisis is caused mainly by corruption, mis-management and the need to protect selfish interests of some group over that of the entire people by leaders or public office holders. Primordial interests breeds corruption, mis-management, looting of public funds in bid to satisfy certain perceived interests. From all the responses gathered, it can be reasonably inferred that governance crisis is a product of mis-management, corruption and looting of public funds. This is because when monies meant for service delivery or distribution of wealth among citizens are diverted to satisfy or meet primordial interests of certain group, crisis in governance is inevitable.

Nevertheless, it has been very glaring that the continual protection of some government officers (Ministers, Special Advisers, Director-Generals and other cronies) who have been found guilty of corruption, looting of public funds and other illicit actions have been responsible for governance crisis in Nigeria. Today, government has lost the trust and support of the people because the present administration in the country seems to be very passive and lukewarm in prosecuting serving ministers and other government functionaries caught with fraudulent practices. The case of Immigration recruitment exercise, where some youths lost their lives in an attempt to secure government job, the case of former minister of Aviation and many others seem to be in consonance with this view. To this end, considering the analysis of data from the key respondents, it can therefore be affirmed that inordinate crave for primordial interest over national interest by cronies of politicians' promote tendency of crisis driven governance in Nigeria and the pursuit of selfish motives and implementation of policies in bid to satisfy primordial motives of politicians' cronies undermine efficient delivery of common good and rule of law in Nigeria.

\section{Policy Redress for Primordial Interests and Governance crisis in Nigeria}

The utility of this paper lies in its ability in revealing that primordial interests as contributing factor to governance crisis in Nigeria is not only caused by political leaders, but also by the cohorts of the public office 
holders who unduly exert pressure on the leaders to satisfy their quest over national interests and these leaders in return loots to fulfil the unquenchable urge of their cronies. In addressing the issue of primordial interests and governance crisis, there is the need for selfless leaders who will be really interested in satisfying national interests over selfish aggrandisement. This view was corroborated by Professor Soyinka (cited in Kennedy-Ukaga, 2007: 25) that leadership is about being selfless, and anyone who wants to be a leader must be ready to sacrifice many things for his/her people. This assertion was reinforced by Owolowo (2012), who points out that "a good leader is meant to be the servant of his/her followers, making necessary sacrifices to achieve greater objectives for the common good". Director (2004:3) advocated for good leaders who are ready to make sacrifice and shun primordial value and embrace national value. Hence, in his words:

A committed leader must simply be competent enough to exercise the duties and responsibilities assigned or trusted on him by virtue of his office and position. Consequently, he must at all times uphold the oath of his office and put smiles on the faces of his people and those who trusted him with responsibilities. A true leader does not run away from challenges, just as he is not expected to be selfish and or serve narrow interests.

The views of Soyinka, Owolowo and Director show that good governance depend largely on patriotic and selfless leaders who shuns their personal gains and that of their cronies for national goals or interests. Nigeria needs leaders who will disobey illicit calls from their ethnic group to steal or loot public treasury and control undue pressure from their cronies.

Also, it on record that some Nigerians are found celebrating or welcoming back home leaders that have been indicted of money laundering and misappropriation of public funds. This should be immediately stopped, as this will earn Nigeria no good name in international system. Comparatively, Nigerian people should learn from developed nations on how to deal with corrupt leaders. In developed democracies people don't celebrate and extend warm hands to confirmed corrupt leaders rather they publicly criticised and monitor the prosecution process of these corrupt leaders. Nigerians should borrow this idea and display such, even if the corrupt person is their family member. This will help to reduce the tendency of stealing and looting in public offices, because when a leader knows that he will be openly criticised and his prosecution will be monitor by members of his family, he will not want to be engaged in it, but when he knows that he will even be praised or be welcomed by his ethnic group or friends, he will not only steal to satisfy himself but to also steal to satisfy his cronies quest. This view was aptly supported by Stanislav Andreski (cited in Osoba, 1996: 377), who contends that in order to meet the selfish and unquenchable desires of the rulers (to satisfy the quest of their cronies) for wealth, public resources and common patrimonies are hijacked and privatized, and this often gives rise to what calls "institutionalized robbery of the state by its very custodians". In bid to address this issue of primordial interests and governance crisis, there is need for the Nigerian people to shun their habitual way of unduly celebrating and shielding corrupt politicians from prosecution or punishment.

Furthermore, there should be critical review of immunity clause in the constitution that exempt serving politicians from prosecution. In Nigeria, most leaders and politicians uses the immunity clause to loot and arbitrarily dispensed state treasury to quench primordial interests of their cronies and themselves. This definitely, has been the bane of governance crisis in the country. This is because these corrupt politicians would have amass huge wealth and be super rich to buy their way to freedom after their tenure in office. For instance, how many of the politicians indicted of corrupt offences while in office are prosecuted after leaving office? Even when they are prosecuted, they are not really sentenced or punished for such offences, observations have shown that such prosecution are for "eye-service" for people to believe that government is working, when in the actual sense they are being lenient to these corrupt leaders.

Finally, government should cut the outrageous cost of governance at all levels of governments. The paper contends that monies and other luxuries those in positions of governance amass is the real cause of governance crisis in Nigeria. Corroborating this view Fakoya (2012), reported that operators of the Nigerian state always make huge budgetary allocations to fund their comfort and luxury. To this end, government should show exemplary life by cutting their excesses in terms of cost of governance at all levels of government, leaders and politicians on the other hand, should let their people (cronies) know that governance is meant to serve the people and not selfish interests of themselves and their cronies. Again, politicians' cronies (ethnic groups, friends, godfathers, party loyalist and family members) should understand that even if their son or friend is the President, Governor or Chairman of Local Government, he is to serve the overall interests of the country and not their own alone. They should equally learn to shun undue celebration of their leaders when they are found guilty of corrupt offences and they should place higher priority on national interests over their ethnic divide or selfish interests. 


\section{Conclusion}

The point has to be made that most of the case of bad governance or governance crisis being experienced in the country are caused not only by leaders but by their cronies who perpetually lure or pressurise leaders to steal and misappropriate public funds in order to satisfy their primordial motives. Analyses of data from key informants in this study confirms that the urge to satisfy the unending selfish interests of the cronies of politicians have been responsible for incessant governance crisis in the country. Corroborating this view was Adekanye (2005), who contends that primordial interests takes the form of some arrangement for power transfer early period of the fourth republic, negotiated by cartels of elite group interests, be they ethnic, social-class based or both. This view was supported by Yagboyaju (2010), who reiterated that Nigeria is largely underdeveloped and confronted by the perennial governance crisis because up till the fourth republic, state offices and public institutions are still exploited as instruments of private accumulation for public officials, their acolytes, kin groups and other vested interests. However, Yagboyaju (2010), argued that the reason why Nigeria is faced with governance crisis in both military and civilian administration is because of absence of a virile private sector or alternative opportunities for material acquisition and social actualisation.

From the foregoing, it is obvious that Nigeria has been very unlucky in terms of the quality of leaders and their supporters who have caused more pains to Nigeria in terms of electoral violence, riots and undue celebration of corrupt leaders. We agree with the view that in Nigeria, leadership is not about service to the people but exploitation of national wealth; to the benefit of few and not the masses. This accounts for why there have been repeatedly poor service delivery of public good, poverty and inequality in spite of numerous endowment of natural resources in Nigeria. All of these according to Diamond (1995), deepened and even took a praetorian character during the long period of military rule in the mid-1980s and up to the late 1990s. The poor masses still live like animals, roaming the jungle in herds, feeding from garbage dumps, drinking from infested springs and sleeping under bridges; and what is clear from Nigeria's historical experience is that a few individuals have arbitrarily tried to animalize the majority, thereby losing their own humanity and rationality in the process (Nwankwo, 1989: 118-119).

The paper brings to notice, that if our leaders and their cronies jettisons their primordial interests for national interests, there will be just delivery of public good to the people, accountability and participation of more people in politics. This will in the long run reduce governance crisis and deepen the country's democracy. Corroborating this view, Yagboyaju (2010), contends that many of the important national events, particularly the general election in 2015, are the parameters that will determine how well Nigeria fared, in terms of management of the governance crisis, under the Jonathan administration.

\section{References}

Abbah, T., Abdulhamid, Y., Idris, A., Hassan, T. A., Ekundayo, K., \& Ogunwale, K. (2012, July 22). Oteh: One Woman, Many Adversaries. Sunday Trust. Retrieved March 16, 2014, from http://www.sundaytrust.com.ng/index.php/11902-oteh-one-woman-many-adversaries

Africa Leadership Forum. (2000). Political parties and good governance in Nigeria. Dialogue 34, 7-9 ${ }^{\text {th }}$ April, Ota Nigeria.

Amuwo, K. (2005). The Peripheral State: Critical Perspectives on the Structure and Role of the Public Bureaucracy. J. Dev. Altern. Area Stud., 24(3-4), 119-130.

Centre for Democracy and Development. (2013). Corruption and Impunity in Nigeria is a major Problem: A response to Mr. President Good luck Jonathan by anti-corruption groups. Retrieved March 22, 2014, from http://cddwestafrica.org/index.php/en/news/159-corruption-and-impunity.htm

Diamond, L. (1995). Nigeria: The Uncivic Society and the Descent into Praetorianism. In Diamond, Linz, \& Lipset (Eds.), Politics in Developing Countries. Boulder, Cororado: Lynne Rienner Publishers.

Director, O. (2004). How Not To Be A Leader. Insider, March 22.

Dobel, J. P. (1978). The Corruption of a State. The American Political Science Review, 72(3), 958-973. http://dx.doi.org/10.2307/1955114

Dommen, E. (1997). Paradigms of Governance and Exclusion. Journal of Modern African Studies, 35, 3. http://dx.doi.org/10.1017/S0022278X97002528

Duke, J. E. (2011). Community Governance and Conflict Resolution as Tools for Managing Development in the Niger Delta Region of Nigeria. International Journal of Business and Commerce, 1(1), 18-31.

Eyinla, B. (2000). The Political transition and the Future democracy in Nigeria. Political science review 
development studies, 1(6), 37.

Fabgbadebo, O., Agunyai, S. C., \& Odeyemi, T. I. (2014). A reflection on political parties as institutions of good governance: Views from Nigeria's presidential system. Being a paper presented at the International Conference on Governance, Peace and Security in Africa, Ambrose Alli University, Ekpoma, Nigeria April 29-30, 2014.

Fakoya, O. (2012). The Town Crier - Seven Kings, Seven Seasons. Retrieved June 7, 2014, from http://www.saharareports.com

Fjeldstad, O., \& Isaksen, J. (2008). Anti-corruption Reforms: Challenges, Effects and Limits of World Bank Support. Background Paper to Public Sector Reform: What Works and Why? An IEGE valuation of World Bank Support.

Inokoba, P., \& Kumokor, I. (2012). Electoral Crisis, Governance and Democratic Consolidation in Nigeria. Journal of Social Science, 27(2), 139-148.

Joseph, R. A. (1991). Democracy and Prebendal Politics in Nigeria: The Rise and fall of the Second Republic. Ibadan, Nigeria: Spectrum Books Ltd.

Joseph, R. A. (1999). Nigeria and the Challenge of Leadership. Tell, July 5.

Joshua, S. (2013). Democracy and Violent Conflicts in Nigeria: Implications for National Development. An International Multidisciplinary Journal, 7(3), 324-339. http://dx.doi.org/10.4314/afrrev.v7i3.23

Kennedy-Ukaga, N. (2007). A Leader Should be Selfless. An interview granted by Professor Wole Soyinka to Sunday Sun, March 18.

Maier, K. (2000). This House Has Fallen: Nigeria in Crisis. London: Penguin Books Ltd.

Nnamani, D. O., \& IIoh, J. O. (2014). Good Governance and National Value: Where Does Nigeria Stand at 53 ? International Journal of Democratic and Development Studies, 2(1), 26-35.

Nnoli, O. (1978). Ethnic Politics in Nigeria. Enugu: Fourth Dimension Publishers.

Nnonyelu, N. A. (2013). Governance Failure, Poverty and Ethno-Sectarian Conflicts in Nigeria: Implications for Sustainable Development. Journal of Sustainable Development in Africa, 15(4), 1-17.

Nwakwo, A. (1989). Before I Die. Enugu, Nigeria: Fourth Dimension Publishing Co. Ltd.

Nye, J. S. (1967). Corruption and Political Development: A Cost-Benefit Analysis. American Political Science Review, LXI(2), 417-427. http://dx.doi.org/10.2307/1953254

Obayelu, A. E. (2007). Effects of Corruption and Economic Reforms on Economic Growth and Development: Lessons from Nigeria. Submitted For 2007 African Economic Conference.

Ogundiya, I. S. (2009). Political Corruption in Nigeria: Theoretical Perspectives and Some Explanations. Anthropologist, 11(4), 281-292.

Ogundiya, I. S. (2010). Corruption: The bane of democratic stability in Nigeria. Current Research Journal of Social Sciences, 2(4), 233-241.

Ojo, E. (2010). A survey of Ethno-Religious Crisis and Its Implications for Nigeria's Nascent Democracy. Journal of Sustainable Development in Africa, 12(2), 182-198.

Oladipo, K. (2013). Being Slow or Being Clueless? Retrieved July 9, 2014, from http://www.saharareporters.com

Ologbenla, D. (2010). Leadership, Governance and Corruption in Nigeria. Journal of Sustainable Development in Africa, 9(3), 97-118.

Oni, S. O. (2013). Legislature-Executive Relations in the Presidential System: A Study of Lagos and Ogun States, Nigeria, 1999-2011. A Ph.D. Thesis Submitted to the Department of Political Science and International Relations, School of Social Sciences, College of Development Studies, Covenant University, Ota, Nigeria.

Osaghae, E. (2001). Ethnic Mapping Project: A Concept. In Osaghae (Ed.), Ethnic group and conflict in Nigeria (Vol. 1). Ibadan PEFS.

Osaghae, E. E. (1994). Trends in Migrant Political Organisation in Nigeria: The Igbo in Kano. Ibadan: French Institute for Research in Africa, University of Ibadan press.

Osimen, G. U., Balogun, A., \& Adenegan, T. S. (2013). Ethnicity and Identity Crisis: Challenge to National Integration in Nigerian. IOSR Journal of Humanities and Social Science, 16(4), 79-86. 
http://dx.doi.org/10.9790/0837-1647986

Osoba, S. O. (1996, September). Corruption in Nigeria: Historical Perspectives. Review of African Political Economy, 23(69). http://dx.doi.org/10.1080/03056249608704203

Owolowo, M. B. O. (2012). The President's Probity Perplexity. Retrieved March 26, 2014, from http://www.saharareproters.com

Premium Times, Wednesday, June 19, 2013 p.7.

United Nations Water Virtual Learning Community. (2011). Lesson 5: Governance and community based approaches. Retrieved October 16, 2014, from http://www.gdrc.org/u-gov/governance-understand.html

United Nations. (1998). Human Development Report.

Vanguard, Saturday, February $16^{\text {th }}, 2008$ pp5-8.

Yagboyaju, D. A. (2010). The State and Governance Crisis in Nigeria: A Comparative Approach. College Press and Publishers Limited.

\section{Copyrights}

Copyright for this article is retained by the author(s), with first publication rights granted to the journal.

This is an open-access article distributed under the terms and conditions of the Creative Commons Attribution license (http://creativecommons.org/licenses/by/3.0/). 